\title{
Mycobacterium avium-intracellulare (MAI) liver abscess mimicking liver metastasis in a patient with rheumatoid arthritis on adalimumab and methotrexate
}

\author{
Takaaki Kobayashi, ${ }^{1}$ Bradley Ford, ${ }^{2}$ Poorani Sekar ${ }^{1}$
}

${ }^{1}$ Internal Medicine, University of lowa Hospitals and Clinics, lowa City, lowa, USA

${ }^{2}$ Pathology, University of lowa Hospitals and Clinics, lowa City, lowa, USA

\section{Correspondence to} Dr Takaaki Kobayashi, taka.kobayashi1126@gmail.com

Accepted 6 June 2019

Check for updates

(C) BMJ Publishing Group Limited 2019. No commercial re-use. See rights and permissions. Published by BMJ.

To cite: Kobayashi T, Ford B, Sekar P. BMJ Case Rep 2019:12:e230912. doi:10.1136/bcr-2019230912

\section{DESCRIPTION}

A 75-year-old man with a history of rheumatoid arthritis (on adalimumab and methotrexate), hiatal hernia and Barrett's oesophagus presented to an outside hospital with a 1 day history of severe vomiting and abdominal pain. CT of the abdomen showed a large paraesophageal hernia, and he was transferred to a tertiary hospital for hernia repair. Physical examination was significant for mild epigastric tenderness. Gastroenterology consultants endoscopically placed a postpyloric enteric tube. After the procedure, the patient developed a high fever of $40^{\circ} \mathrm{C}$ and CT of chest/abdomen/pelvis with contrast was performed, which revealed multiple hypodense lesions in the liver (figure 1A,B). MRI of the liver with contrast demonstrated ring-enhancing lesions and malignancy was suspected (figure 2A,B). Surgical repair of the hernia was cancelled and a liver biopsy was performed. Pathology showed lymphohistiocytic infiltrate with acid-fast bacilli (AFB) consistent with mycobacteria (figure 3A,B). No malignant cells were seen. Both AFB blood culture and tissue culture grew Mycobacterium avium-in tracellulare (MAI). The patient was diagnosed with disseminated MAI infection with liver abscess. All immunosuppressants were held and he was started on azithromycin, ethambutol, rifampin and amikacin for severe disseminated MAI infection.

Non-tuberculous mycobacteria (NTM) are mycobacterial species other than those belonging to the Mycobacterium tuberculosis complex and $\mathrm{Myco}$ bacterium leprae. Molecular identification techniques, including whole-genome sequencing, have identified $\sim 200$ NTM species. ${ }^{1}$ Mycobacterium avium complex (MAC) organisms are ubiquitous in the environment and thus easily encountered. Among NTM, MAC is the most common cause of pulmonary disease worldwide. ${ }^{1}$ Disease due to MAC manifests as chronic pneumonia, acute hypersensitivity pneumonitis, skin, soft tissue, bone and

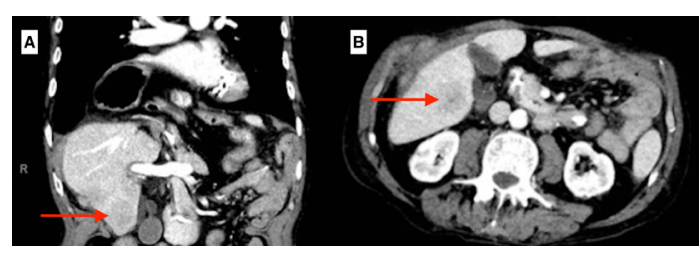

Figure $1 \quad(A, B) C T$ showed hypodensities in segment 5 and 6 in the liver suspicious for mass lesions.

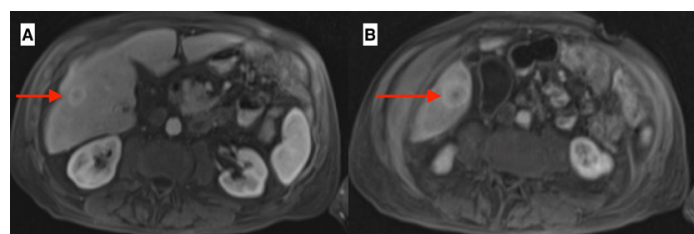

Figure $2(A, B) M R I$ with contrast showed multiple ringenhancing lesions with targetoid apperance in segments 5,6 and 8 some of which show diffusion restriction, concerning for metastatic cancer.

disseminated infection. Liver abscess due to MAC is rarely reported..$^{2}$ In North America, mean annual period prevalence between 2004 and 2006 was reported to be 5.5 cases per 100000 population. ${ }^{3}$ Disseminated MAC disease primarily occurs in severely immunocompromised patients, such as those with advanced HIV infection, haematological malignancy or a history of immunosuppressive therapy including therapy with tumour necrosis factor alpha inhibitors. ${ }^{4-6}$ Clinically, disseminated MAC manifests as intermittent or persistent fever $(>80 \%)$, night sweats $(>35 \%)$ and weight loss $(>25 \%)$, with additional symptoms including fatigue, malaise and anorexia. ${ }^{67}$ The diagnosis is most readily established by culture of blood for mycobacteria. In cases where histopathology is obtained before infection is suspected, additional microbiological studies are helpful as morphologically distinguishing NTM species from each other and from M. tuberculosis can be difficult. ${ }^{8}$ While limited data are available to guide management of disseminated MAC in patients without HIV infection, a multidrug regimen similar to pulmonary MAC disease (a macrolide, ethambutol, a rifamycin

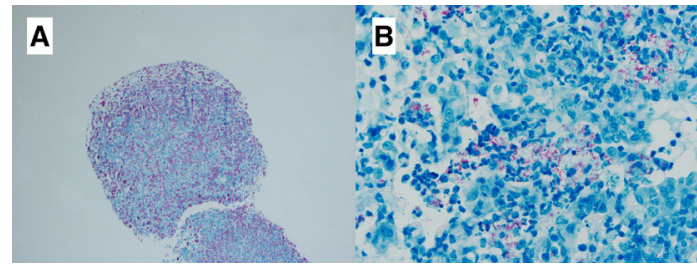

Figure $3 \quad(A, B)$ Surgical biopsy showed extensive inflammatory infiltrate with large aggregates of foamy macrophages. Acid-fast stain highlights numerous acidfast bacilli within these macrophages, consistent with mycobaterial infection. 


\section{Learning points}

- Mycobacterium avium complex (MAC) infection can manifest as liver abscess and mimic liver malignancy, although it is extremely rare.

- Disseminated non-tuberculous mycobacterial infection needs to be considered in the differential diagnosis of patients with fever, night sweats and weight loss who are on tumour necrosis factor inhibitors.

- Disseminated MAC infections are treated with a multidrug regimen (macrolide, ethambutol, rifamycin combination) similar to that used for pulmonary MAC infection.

combination) is generally used for patients with macrolide-susceptible disease and continued for 12 months. ${ }^{6}$ A parenteral aminoglycoside, such as amikacin, is sometimes used as a fourth drug for patients with extensive, severe or life-threatening disease during the initial 8-12 weeks of therapy, although data are limited.

Contributors TK wrote the first draft of the manuscript. PS and BF critically reviewed and revised the manuscript. All authors read and approved the final paper.

Funding The authors have not declared a specific grant for this research from any funding agency in the public, commercial or not-for-profit sectors.
Competing interests None declared.

Patient consent for publication Obtained.

Provenance and peer review Not commissioned; externally peer reviewed.

\section{REFERENCES}

1 Egelund EF, Fennelly KP, Peloquin CA. Medications and monitoring in nontuberculous mycobacteria infections. Clin Chest Med 2015;36:55-66.

2 Laramore AP, Rubinas TC, Varnholt H. Mycobacterium avium complex in the liver. Ann Hepatol 2009:8:241.

3 Prevots DR, Shaw PA, Strickland D, et al. Nontuberculous mycobacterial lung disease prevalence at four integrated health care delivery systems. Am J Respir Crit Care Med 2010;182:970-6.

4 Weinstock DM, Feinstein MB, Sepkowitz KA, et al. High rates of infection and colonization by nontuberculous mycobacteria after allogeneic hematopoietic stem cell transplantation. Bone Marrow Transplant 2003;31:1015-21.

5 Lai CC, Lee LN, Ding LW, et al. Emergence of disseminated infections due to nontuberculous mycobacteria in non-HIV-infected patients, including immunocompetent and immunocompromised patients in a university hospital in Taiwan. J Infect 2006:53:77-84.

6 Griffith DE, Aksamit T, Brown-Elliott BA, et al. An official ATS/IDSA statement: diagnosis, treatment, and prevention of nontuberculous mycobacterial diseases. Am J Respir Crit Care Med 2007;175:367-416.

7 Corti M, Palmero D. Mycobacterium avium complex infection in HIVIAIDS patients. Expert Rev Anti Infect Ther 2008;6:351-63.

8 Jain D, Ghosh S, Teixeira L, et al. Pathology of pulmonary tuberculosis and nontuberculous mycobacterial lung disease: Facts, misconceptions, and practical tips for pathologists. Semin Diagn Pathol 2017;34:518-29.

Copyright 2019 BMJ Publishing Group. All rights reserved. For permission to reuse any of this content visit

https://www.bmj.com/company/products-services/rights-and-licensing/permissions/

BMJ Case Report Fellows may re-use this article for personal use and teaching without any further permission.

Become a Fellow of BMJ Case Reports today and you can:

- Submit as many cases as you like

- Enjoy fast sympathetic peer review and rapid publication of accepted articles

- Access all the published articles

Re-use any of the published material for personal use and teaching without further permission

Customer Service

If you have any further queries about your subscription, please contact our customer services team on +44 (0) 2071111105 or via email at support@bmj.com.

Visit casereports.bmj.com for more articles like this and to become a Fellow 